DOI: 10.19112/2413-6174-2021-S1-07

\title{
ХАРАКТЕРИСТИКА ПРОЯВЛЕНИЙ ДИФФУЗНОГО НЕТОКСИЧЕСКОГО ЗОБА КАК МАРКЕРА БИОЭЛЕМЕНТНОГО СТАТУСА ЧЕЛОВЕКА
}

\author{
E.C. Барышева \\ Оренбургский государственный университет, 460013, г. Оренбург, пр. Победы, 13 \\ e-mail: baryshevae@mail.ru
}

РЕЗЮМЕ. Известно, что йод играет ключевую роль в структурно-функциональном состоянии щитовидной железы. Однако в формировании относительного йодного дефицита принимают участие такие струмогенные факторы, как токсичные химические элементы. При этом нарушаются патогенетические механизмы регуляции щитовидной железы на уровне гипоталамо-гипофизарной нейроэндокринной системы. Целью работы было изучение роли микроэлементов в формировании структуры и функции щитовидной железы, а также органов регуляции. Изучен элементный статус у 611 работников промышленных предприятий. Исследование концентрации химических элементов в образцах выполнено в АНО «Центр биотической медицины» (Москва). Для верификации диффузного нетоксического зоба проведено исследование уровня гормонов $\mathrm{T}_{3}$ (общий), Т 4 (свободный), ТТГ в сыворотке крови (ИФА, тест-наборы). Установлена закономерность между уровнем накопления эссенциальных и токсичных микроэлементов в волосах и изменением структуры и функции щитовидной железы у работников вредных производств.

КЛЮЧЕВЫЕ СЛОВА: химические элементы, щитовидная железа, вредные факторы производства.

\section{CHARACTERISTICS OF THE MANIFESTATIONS OF DIFFUSE NON-TOXIC GOITER AS A MARKER OF HUMAN BIOELEMENT STATUS E.S. Barysheva \\ Orenburg State University, 460013, Orenburg, Pr. Pobedy, 13 e-mail: baryshevae@mail.ru}

\begin{abstract}
It is known that iodine plays a key role in the structural and functional state of the thyroid gland. However, such strumogenic factors as toxic chemical elements are involved in the formation of a relative iodine deficiency. In this case, the pathogenetic mechanisms of thyroid regulation at the level of the hypothalamic-pituitary neuroendocrine system are disrupted. The aim of our study was to study the role of trace elements in the formation of the structure and function of the thyroid gland, as well as the regulatory organs. A study of the elemental status of 611 employees of industrial enterprises working under the influence of harmful factors of production was conducted. The study of the concentration of chemical elements in the samples was carried out in the ANO "Center for Biotic Medicine", Moscow. To verify the diffuse non-toxic goiter, the level of hormones $\mathrm{T}_{3}$ (total), $\mathrm{T}_{4}$ (free), TSH in the blood serum and ELISA test kits were studied. A pattern was established between the level of accumulation of essential and toxic trace elements in the hair and changes in the structure and function of the thyroid gland in workers with harmful working conditions.
\end{abstract}

KEYWORDS: chemical elements, thyroid gland, harmful factors of production.

\section{ВВЕДЕНИЕ}

Йод играет ключевую роль в структурно-функциональном состоянии щитовидной железы. Известно, что токсичные химические элементы оказывают влияние на формирование относительного йодного дефицита. При этом нарушаются патогенетические механизмы регуляции щитовидной железы на уровне гипоталамо-гипофизарной нейроэндокринной системы.

Цель работы - изучение роли микроэлементов в формировании структуры и функции щитовидной железы, а также органов регуляции.

\section{РЕЗУЛЬТАТЫ И ОБСУЖДЕНИЕ}

В результате проведенных исследований была установлена линейная зависимость частоты отклонений концентрации йода от рекомендуемой нормы с концентрацией токсичных металлов в волосах работников вредных производств (Bertram, 1992; с доп. А.В. Скального, 2003) (рисунок). 


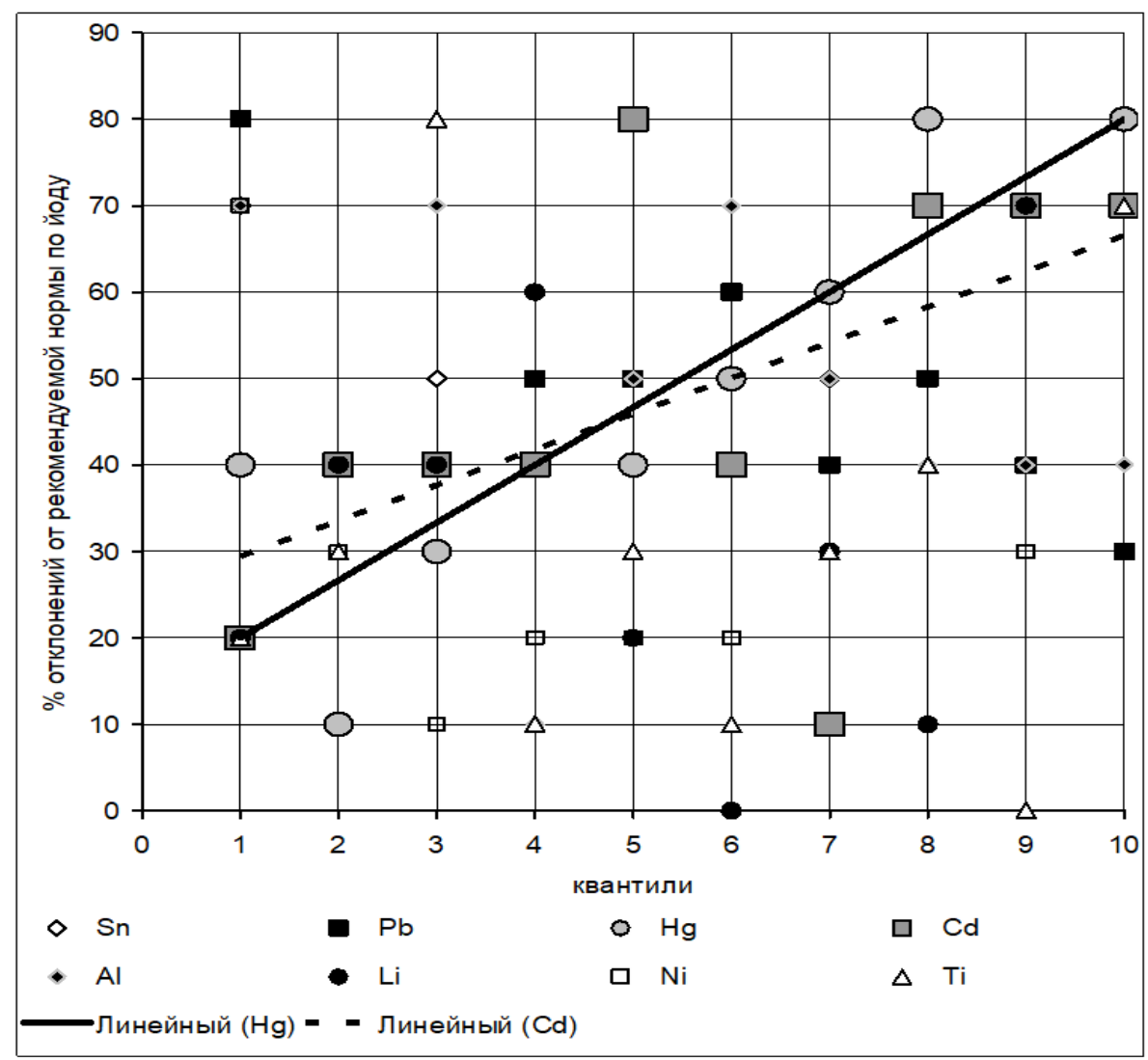

Рисунок. Связь частоты отклонений концентрации йода от рекомендуемой нормы с концентрацией токсичных металлов в волосах работников вредных производств

Несмотря на то, что среднее содержание йода в волосах у всех обследованных находилось в пределах референтных значений, была осуществлена выборка индивидуальных показателей, которые оказались выше или ниже нормативных значений (Iyengar, 1988), с последующим проведением УЗИдиагностики щитовидной железы у данной категории обследуемых (таблица).

\section{ВЫВОДЫ}

Установлен способ прогнозирования диффузного нетоксического зоба у людей, занятых на вредных производствах, на основании следующих закономерностей: снижение концентрации йода в волосах сопровождается диффузными нарушениями структуры щитовидной железы, а повышенный уровень приводит к диффузно-узловой гиперплазии.

Таблица. Средние концентрации йода в волосах и показатели структурных нарушений щитовидной железы у обследуемых

\begin{tabular}{|l|c|c|c|}
\hline \multicolumn{1}{|c|}{ Параметр } & $\begin{array}{c}\text { Пониженный уровень йода } \\
\text { в волосах }(n=28)\end{array}$ & $\begin{array}{c}\text { Контроль } \\
(n=46)\end{array}$ & $\begin{array}{c}\text { Повышенный уровень йода } \\
\text { в волосах } \\
(n=26)\end{array}$ \\
\hline Содержание йода в волосах, мкг/г & $\leq 0,27$ & $0,27-4,20$ & $18,83 \pm 3,4$ \\
\hline Средняя концентрация йода в волосах, мкг/г & $0,22 \pm 0,1$ & $1,17 \pm 0,1$ & $16,06 \pm 2,34$ \\
\hline Средний объем щитовидной железы, см ${ }^{3}$ & $14,12 \pm 3,8$ & $13,05 \pm 1,25$ & Норма \\
\hline УзИ щитовидной железы & Умеренные диффузные & Диффузно-узловая гиперплазия \\
\hline
\end{tabular}




\section{Cиисок литературы / References}

1. Скальный А.В. Референтные значения концентрации химических элементов в волосах, полученные методом ИСП-АЭС. Микроэлементы вмедицине. 2003; 4(1): 55-56.

2. Iyengar $V$., Woittiez J. Trace elements in human clinical specimens: evaluation of literature data to identity references values. Clin. Chem. 1998; 34(1): 474-481.

3. Bertram H.P. Spurenelemente: Analytik, okotoxikologische und medizinisch - klinische Bedeutung. Munchen; Wien; Baltimore : Urban und Schwarzenberg, 1992. 207 p. 